\title{
Macrophage chemiluminescence induced by interaction with transparent and opaque colonial variants of Mycobacterium intracellulare
}

\author{
HARUAKI TOMIOKA* and HaJime SaIto \\ Department of Microbiology and Immunology, Shimane Medical University, Izumo 693, Japan
}

(Received 18 January 1993; revised 10 June 1993; accepted 20 July 1993)

\begin{abstract}
Macrophage (MФ) chemiluminescence (CL) induced by interaction with the two types of colonial variants of Mycobacterium intracellulare was studied. A smooth, opaque and dome-shaped (SmD) colonial variant triggered more intense МФ CL than did a smooth, transparent and flat colonial variant (SmT). MФ CL-inducing activity of the SmD variant was reduced by heating or by treatments with either Pronase $P$, some endoglycosidases or Tween 80, thereby indicating that the SmD variant possesses MФ CL-inducing substance(s) having peptide, sugar and/or lipid-like moieties. Treatment of the $\mathrm{SmD}$ variant organism with some endoglycosidases, such as cellulase, pectinase, dextranase or $\alpha$-amylase decreased its MФ CL-inducing ability. On the other hand, MФ CL-inducing activity of the SmT variant was not affected by any of above treatments except that it was slightly increased by Pronase $P$ treatment and reduced by $\alpha$-amylase and dextranase.
\end{abstract}

\section{Introduction}

Two smooth colonial variants are known in the Mycobacterium avium-intracellulare complex (MAC) (Schaefer et al., 1970; Woodley \& David, 1976); a transparent, flat and irregularly shaped colony (SmT variant) and an opaque and dome-shaped colony ( $\mathrm{SmD}$ variant). These variants differ from each other in biological properties and in virulence for mice and birds (Saito \& Tomioka, 1988, 1990; Schaefer et al., 1970; Woodley \& David, 1976). Saito \& Tomioka (1990) and Gangadharam \& Edwards (1984) found that the SmT variants have higher virulence for mice and conversely much reduced activity in inducing the macrophage (MФ) respiratory burst which is important for the expression of microbicidal activity of MФs (Johnston, 1978) (measured in terms of chemiluminescence (CL) and $\mathrm{O}_{2}^{-}$production), as compared to the $\mathrm{SmD}$ variant. Although recent studies have indicated the importance of nitric oxide for the expression of antimicrobial action against some intracellular parasites, at least in mice (Adams et al., 1990; Flesch \& Kaufmann, 1991; Liew et al., 1990; Park \& Rikihisa, 1992), it is also known that the low ability of

\footnotetext{
*Author for correspondence. Tel. +81853232111 ; fax +8185321
} 9220.

Abbreviations: $\mathrm{M} \Phi$, macrophage; $\mathrm{CL}$, chemiluminescence; HBSS, Hanks' balanced salt solution; MAC, Mycobacterium aviumintracellulare complex. the SmT variant to induce $M \Phi$ respiratory burst is closely related to its resistance to the microbicidal action of host MФs (Saito \& Tomika, 1990). In this study, we investigated some properties of the M $\Phi$ CL-inducing substance(s) of $M$. intracellulare and found that it possesses peptide and/or sugar moieties.

\section{Methods}

Organisms. $M$. intracellulare N-257 (serovar 13), N-260 (serovar 16) and N-275 (serovar determination was impossible because of autoagglutination), identified using the Gen-Probe Rapid Diagnostic System for the MAC (Gen-Probe) were used. From these strains, SmT and $\mathrm{SmD}$ variants were isolated on $7 \mathrm{H} 10$ agar plates by repeating three to four transfers. An isolated colony was inoculated into $7 \mathrm{H} 9$ medium and cultivated for 1 week to obtain a stem culture. The stem culture $(0.1 \mathrm{ml})$ was further transferred to $5 \mathrm{ml} 7 \mathrm{H} 9$ medium and cultivated for 1 week. The resultant culture $(0.1 \mathrm{ml})$ was used as inoculum for $7 \mathrm{H} 10$ agar plates; after 7-10 d the organisms were used for measurement of MФ CL-inducing ability. The SmT and SmD variants were streaked on $7 \mathrm{H} 10$ agar plates, cultivated for $10 \mathrm{~d}$, and checked for purity of each colony morphology.

Mice. $\mathrm{C} 57 \mathrm{BL} / 6$ (Bcgs; MAC-susceptible strain) and $\mathrm{C} 3 \mathrm{H} / \mathrm{He}$ or $\mathrm{CBA} / \mathrm{JN}$ (Bcgr; MAC-resistant strains) mice were used (Goto et al., 1984; Skamene, 1989). The first two mouse strains were purchased from Japan SLC and CBA/JN mice were obtained from Charles River.

Special agents. $\alpha$-Amylase (Type IX-A, from human saliva), isoamylase (from Pseudomonas amyloderamosa), cellulase (type II, from Aspergillus niger), dextranase (from Penicillium sp.), hyaluronidase (type I-S, from bovine testis), laminarinase (from Penicillium sp.), pullulanase (from Enterobacter aerogenes), and pectinase (from Rizopus sp.) were obtained from Sigma. Pronase $\mathrm{P}$ was purchased from Kaken Kayaku Co. 
Physical and chemical treatments of $M$. intracellulare. $\mathrm{SmT}$ or $\mathrm{SmD}$ variants of $M$. intracellulare $\mathrm{N}-260$ cultured on $7 \mathrm{H} 10$ agar plates in a $\mathrm{CO}_{2}$ incubator $\left(5 \% \mathrm{CO}_{2}-95 \%\right.$ humidified air) at $37^{\circ} \mathrm{C}$ for $7-10 \mathrm{~d}$ were harvested by gently scraping into distilled water to minimize the contamination of medium constituents, washed once with distilled water by centrifugation $(1500 \mathrm{~g}, 15 \mathrm{~min})$, suspended in distilled water and gently sonicated with a Handy Sonic (Model UR-20P, Tomy Seiko Co.) for $15 \mathrm{~s}$ to disperse bacterial clumps. No cell destruction was observed. After centrifugation at $200 \mathrm{~g}$ for $5 \mathrm{~min}$ to remove remaining bacterial clumps, the bacterial suspension $\left(1-2 \times 10^{9} \mathrm{cells} \mathrm{ml}^{-1}\right)$ was subjected to the following treatments: heating at $100^{\circ} \mathrm{C}$, for $15 \mathrm{~min}$, or treatment with $3 \%(\mathrm{v} / \mathrm{v})$ formalin in $0.1 \mathrm{M}$-Tris $/ \mathrm{HCl}, \mathrm{pH} 7.5$, at $37^{\circ} \mathrm{C}$ for $2 \mathrm{~h}$; or Pronase $\mathrm{P}\left(0.8 \mathrm{mg} \mathrm{m}^{-1}\right.$ in $0.1 \mathrm{M}$-Tris $/ \mathrm{HCl}, \mathrm{pH} 7.5$, containing $8 \mathrm{~mm}-\mathrm{CaCl}_{2}$ ) at $37^{\circ} \mathrm{C}$ for $2 \mathrm{~h}$.

Endoglycosidase treatments were done under the optimum condition for each enzyme (Dorfman, 1955; Fukumoto et al., 1971; Kertesz, 1955; Mercier et al., 1972; Moore \& Stone, 1972; Nishizawa et al., 1978; Thoma et al., 1971) as follows: $\alpha$-amylase $\left(50 \mathrm{U} \mathrm{ml}^{-1}\right)$ in phosphate-buffered saline (PBS: $0.15 \mathrm{M}-\mathrm{NaCl}, 1.3 \mathrm{~mm}-\mathrm{KCl}, 1.5 \mathrm{~mm}-$ $\mathrm{KH}_{2} \mathrm{PO}_{4}, 8 \cdot 1 \mathrm{M}-\mathrm{Na}_{2} \mathrm{HPO}_{4}$ ), $\mathrm{pH} 7 \cdot 2$, at $40^{\circ} \mathrm{C}$ for $2 \mathrm{~h}$; isoamylase $\left(50 \mathrm{U} \mathrm{ml}^{-1}\right)$ in $\mathrm{PBS}, \mathrm{pH} 7 \cdot 2$, with $5 \mathrm{~mm}$-ammonium sulphate at $40^{\circ} \mathrm{C}$ for $2 \mathrm{~h}$; cellulase $\left(10 \mathrm{U} \mathrm{ml}^{-1}\right)$ in $0.1 \mathrm{M}$-sodium acetate, $\mathrm{pH} 4 \cdot 0$, at $30^{\circ} \mathrm{C}$ for $2 \mathrm{~h}$; dextranase $\left(10 \mathrm{U} \mathrm{ml}^{-1}\right)$ in $50 \mathrm{~mm}$-sodium acetate, $\mathrm{pH} 5.0$, at $40{ }^{\circ} \mathrm{C}$ for $2 \mathrm{~h}$; hyaluronidase $\left(50 \mathrm{U} \mathrm{ml}^{-1}\right)$ in $20 \mathrm{~mm}$-sodium phosphate, $\mathrm{pH} 7.0$, containing $0.45 \% \mathrm{NaCl}$ and $0.01 \%$ bovine serum albumin at $37^{\circ} \mathrm{C}$ for $2 \mathrm{~h}$; laminarinase $\left(0.5 \mathrm{U} \mathrm{ml}^{-1}\right)$ in $50 \mathrm{~mm}$-sodium acetate, pH 5.0 , at $40^{\circ} \mathrm{C}$ for $2 \mathrm{~h}$; pullulanase $\left(1 \mathrm{U} \mathrm{ml}^{-1}\right)$ in $20 \mathrm{~mm}$-citrate/ phosphate with $0.16 \mathrm{M}$-ammonium sulphate, $\mathrm{pH} 5 \cdot 0$, at $30^{\circ} \mathrm{C}$ for $2 \mathrm{~h}$; pectinase $\left(50 \mathrm{U} \mathrm{ml}^{-1}\right)$ in $0 \cdot 1 \mathrm{M}$-sodium acetate, $\mathrm{pH} 4 \cdot 0$, at $25^{\circ} \mathrm{C}$ for $2 \mathrm{~h}$; $1 \%(\mathrm{w} / \mathrm{v})$ Tween 80 in PBS, $\mathrm{pH} 7 \cdot 2$, at $37^{\circ} \mathrm{C}$ for $6 \mathrm{~h}$. After each treatment, the organisms were washed four times with distilled water by centrifugation at $20000 \mathrm{~g}$ for $20 \mathrm{~min}$, resuspended in distilled water, sonicated with a Handy Sonic for $15 \mathrm{~s}$, and centrifuged at $200 \mathrm{~g}$ for $5 \mathrm{~min}$ before testing for MФ CL-inducing activity. Counts of bacteria were made after Ziehl-Neelsen staining using $1 \%(\mathrm{v} / \mathrm{v}) \mathrm{HCl} /$ ethanol for decolorization. In some cases, counting of c.f.u. was done by plating on $7 \mathrm{H} 10$ agar medium.

$M \Phi C L$. This was measured as previously reported (Yamada et al., 1987). Briefly, peritoneal exudate cells of mice $\left(2.5 \times 10^{6}\right.$ cells $)$, harvested $4 \mathrm{~d}$ after intraperitoneal injection of zymosan $\mathrm{A}(1 \mathrm{mg})$, were incubated at $37^{\circ} \mathrm{C}$ for up to $10 \mathrm{~min}$ in the following reaction mixture ( $1 \mathrm{ml}$ in $13 \times 32 \mathrm{~mm}$ vial) : $1 \mathrm{ml}$ phenol red/free Hanks' balanced salt solution (HBSS) containing $10 \mathrm{~mm}$-HEPES, pH 7.4 and $0.1 \mathrm{mm-}$ luminol with or without the addition of the indicated amount of SmT or $\mathrm{SmD}$ colonial variant of $M$. intracellulare. Photoemission was measured using an ATP lumiphotometer, Lumicounter ATP-237 (Tokyo Kagaku) at $37^{\circ} \mathrm{C}$ for $10 \mathrm{~s}$ at 1 or $2 \mathrm{~min}$ intervals for up to $10 \mathrm{~min}$.

Since the intensity of MФ CL induced by MAC organisms varied considerably from experiment to experiment depending on the functional state of harvested $M \Phi s$, interexperimental mean values could not be estimated even when the M $\Phi \mathrm{CL}$ assay was carried out under the same conditions.

Estimation of the number of $M \Phi$-associated organisms. The number of $M \Phi$-associated (attached or phagocytosed) organisms during the incubation for MФ CL measurement was estimated as follows. The incubation mixture was washed four times with HBSS containing $5 \%$ (v/v) foetal bovine serum (FBS) (M. A. Bioproducts) by centrifugation at $50 \mathrm{~g}$ for $5 \mathrm{~min}$ to remove attached organisms and the resultant cell pellet was suspended in $1 \mathrm{ml} 10 \% \mathrm{FBS} / \mathrm{RPMI} 1640$ medium, placed in multi-well plates (Corning; 24 wells) and incubated at $37^{\circ} \mathrm{C}$ in a $\mathrm{CO}_{2}$ incubator $\left(5 \% \mathrm{CO}_{2} / 95 \%\right.$ air) for $30 \mathrm{~min}$. After thorough washing with HBSS, the MФ culture was subjected to Ziehl-Neelsen staining and counted.

\section{Results}

\section{$M \Phi C L$-inducing ability of $S m T$ and $S m D$ colonial} variants

Fig. 1 shows $\mathrm{CL}$ from $\mathrm{M} \Phi$ s of $\mathrm{C} 3 \mathrm{H} / \mathrm{He}\left(\mathrm{Bcg}^{\mathrm{r}}\right)$ and $\mathrm{C} 57 \mathrm{BL} / 6\left(\mathrm{Bcg}^{\mathrm{s}}\right)$ mice triggered with the two colonial variants of $M$. intracellulare strain $\mathrm{N}-260$. In both $\mathrm{Bcg}^{\mathrm{r}}$ and $B \mathrm{cg}^{\mathrm{s}} \mathrm{M} \Phi \mathrm{s}$, the $\mathrm{SmD}$ variant induced higher $\mathrm{M} \Phi \mathrm{CL}$,

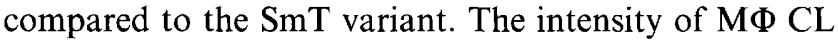
induced by the $\mathrm{SmD}$ variant was higher in $\mathrm{Bcg}^{\mathrm{r}} \mathrm{M} \Phi \mathrm{s}$ than in $\mathrm{Bcg}^{\mathrm{s}} \mathrm{M} \Phi$ s. Fig. 1 also shows that MФ CL induced by the $\mathrm{SmD}$ variant was not affected by the addition of SmT variant, indicating that the SmT variant exerted no inhibitory action against MФ CL. Similar results were obtained for other $M$. intracellulare strains, N-257 and $\mathrm{N}-275$, although the intensity of MФ CL varied depending on strain of the MAC. Cumulative $\mathrm{CL}\left(10^{6}\right.$ counts per tube) from $\mathrm{C} 3 \mathrm{H} / \mathrm{He} \mathrm{M} \Phi$ s induced by $\mathrm{N}-257, \mathrm{~N}-260$ and $\mathrm{N}$-275 strains (added at $10^{9}$ c.f.u. per tube) during a $10 \mathrm{~min}$ incubation was as follows: $\mathrm{N}-257, \mathrm{SmD}(3 \cdot 3)$, SmT (1.0); N-260, SmD (21.4), SmT (1.1); N-275, SmD (6.4), SmT (0.9). Similarly, the cumulative CL from C57BL/ 6 MФs induced by N-260 and N-275 strains was as follows: $\mathrm{N}-260, \mathrm{SmD}(2 \cdot 0), \mathrm{SmT}(0 \cdot 6) ; \mathrm{N}-275, \mathrm{SmD}$ $(4 \cdot 6), \operatorname{SmT}(0 \cdot 7)$.

In a separate experiment with $\mathrm{C} 3 \mathrm{H} / \mathrm{He} \mathrm{M} \Phi \mathrm{s}$, the number of $\mathrm{M} \Phi$-associated organisms of $M$. intracellulare $\mathrm{N}-260 \mathrm{SmD}$ variant was about $2 \cdot 2$ times greater than that of the SmT variant. During a $10 \mathrm{~min}$ incubation for $\mathrm{M \Phi}$ CL measurement, $5 \cdot 0 \pm 0 \cdot 1$ and $2 \cdot 3 \pm 0 \cdot 5$ organisms of $\mathrm{SmD}$ and SmT variants, respectively, were caught by one $\mathrm{M \Phi}$, when $5 \times 10^{8}$ organisms were added without opsonin. In this case, the intensity of M $\Phi \mathrm{CL}$ induced by

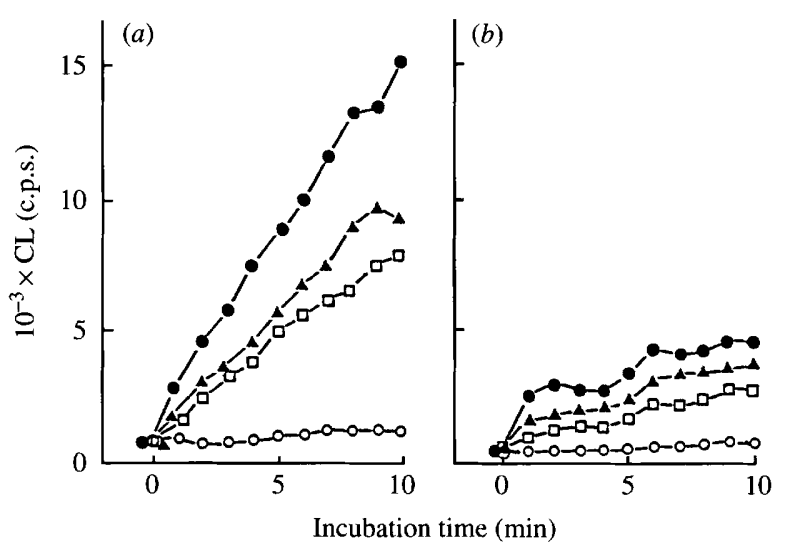

Fig. 1. Photoemission from MФs induced with $\mathrm{SmT}$ and $\mathrm{SmD}$ variants

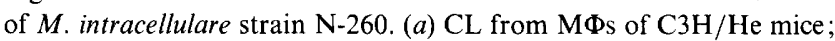
$\mathrm{O}, \operatorname{SmT}\left(8.5 \times 10^{8}\right.$ per tube $) ; \boldsymbol{\bullet}, \operatorname{SmD}\left(6.3 \times 10^{8}\right) ; \boldsymbol{\Lambda}, \operatorname{SmD}\left(3 \cdot 1 \times 10^{8}\right)$; $\square, \operatorname{SmT}\left(4 \cdot 2 \times 10^{8}\right)+\operatorname{SmD}\left(3 \cdot 1 \times 10^{8}\right)$. (b) CL from M $\Phi$ s of C $57 \mathrm{BL} / 6$ mice; $\bigcirc, \operatorname{SmT}\left(1.7 \times 10^{9}\right.$ per tube);, $\mathrm{SmD}\left(1.3 \times 10^{9}\right) ; \boldsymbol{\Delta}, \mathrm{SmD}$ $\left(6.3 \times 10^{8}\right) ; \square, \operatorname{SmT}\left(8.5 \times 10^{8}\right)+\operatorname{SmD}\left(6.3 \times 10^{8}\right)$. A representative result obtained in one of four separate experiments is indicated. Reproducibility of this result was confirmed in the other experiments. 


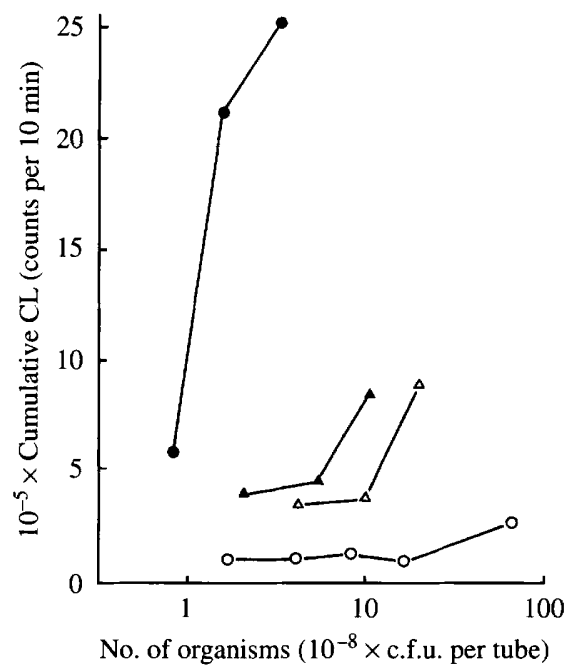

Fig. 2. MФ CL-inducing activities of $\operatorname{SmT}(O, \triangle)$ and $\operatorname{SmD}(\boldsymbol{\Delta}, \boldsymbol{\Delta})$ variants of $M$. intracellulare strain $\mathrm{N}-260$ grown on $7 \mathrm{H} 10$ medium $(\mathrm{O}$, -) and Ogawa egg medium $(\triangle, \boldsymbol{\Delta}) . \mathrm{M} \Phi$ photoemission was measured $10 \mathrm{~min}$ after the addition of organisms. $\mathbf{M \Phi s}$ were obtained from $\mathrm{C} 3 \mathrm{H} / \mathrm{He}$ mice.

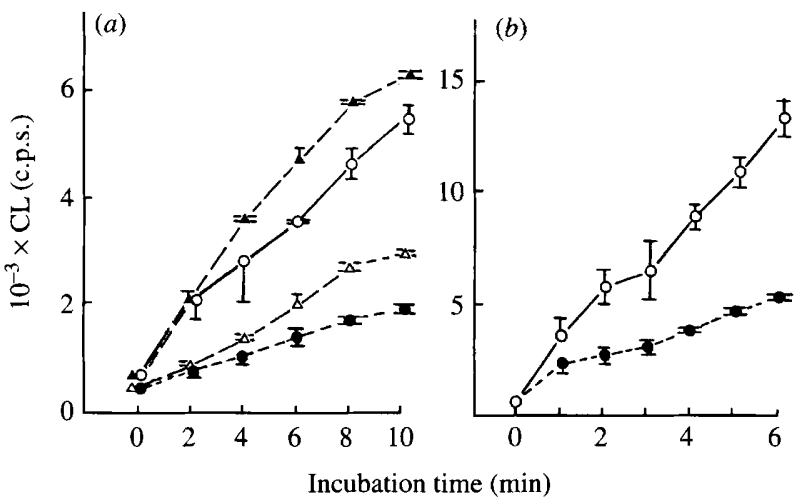

Fig. 3. Effects of physical and chemical treatments of the $\mathrm{SmD}$ colonial variant of $M$. intracellulare $\mathrm{N}-260$ on its $\mathrm{M} \Phi \mathrm{CL}$-inducing activity. $\mathrm{M \Phi s}$ were obtained from $\mathrm{C} 3 \mathrm{H} / \mathrm{He}$ mice. (a) $\bigcirc$, Control (untreated); $\triangle$, heating $\left(100^{\circ} \mathrm{C}, 15 \mathrm{~min}\right) ; 0$, Pronase $\mathrm{P}$ treatment $\left(0.8 \mathrm{mg} \mathrm{m}^{-1}\right.$, $2 \mathrm{~h}) ; \boldsymbol{\Delta}, 3 \%(\mathrm{v} / \mathrm{v})$ formalin treatment $(2 \mathrm{~h})$. (b) $\bigcirc$, Control (untreated); - $1 \%(\mathrm{w} / \mathrm{v})$ Tween 80 treatment $(2 \mathrm{~h})$. Each plot indicates the mean \pm SD $(n=2$ or 3$)$. The SD bars smaller than the size of each symbol were omitted. The $95 \%$ confidence limit of the variation of plots indicated in individual symbols was as follows. $(a) \bigcirc$, $\pm 1.03 \times 10^{3}$ c.p.s.; $\triangle, \pm 0.09 \times 10^{3}$ c.p.s.; $\mathbf{O}, \pm 0.13 \times 10^{3}$ c.p.s.; $\Delta$. $\pm 0.15 \times 10^{3}$ c.p.s. (b) $\bigcirc, \pm 1 \cdot 14 \times 10^{3}$ c.p.s.;, $\pm 0.27 \times 10^{3}$ c.p.s.

the SmD variant was about $6 \cdot 4$-fold greater than that induced by the $\mathrm{SmT}$ variant: $3.4 \times 10^{3}(\mathrm{SmD})$ versus $5.3 \times 10^{2}(\mathrm{SmT})$ c.p.s. per $10^{6} \mathrm{M} \Phi$ s. Therefore, the difference in the number of attached organisms of the $\mathrm{SmD}$ and SmT variants on MФs is not a main cause for the lowered MФ CL-triggering activity of the SmT variant compared to that of the $\mathrm{SmD}$ variant.

Fig. 2 compares $M \Phi C L$ induced by the SmT and SmD variants grown on $7 \mathrm{H} 10$ agar medium or Ogawa egg medium (Ogawa \& Saba, 1949). The intensity of MФ CL was in the order: $\mathrm{SmD}$ on $7 \mathrm{H} 10$ medium $>\mathrm{SmD}$ on Ogawa egg medium $\geqslant$ SmT on Ogawa egg medium $>$ SmT on $7 \mathrm{H} 10$ medium. In the case of MAC organisms grown on Ogawa egg medium, there was only a small difference in the M $\Phi$ CL-inducing activity between the SmT and SmD variants. Therefore, the differential $M \Phi$ CL-inducing activities of the SmT and SmD variants are not a fixed characteristic but are expressed depending on the nutrient conditions of the bacterial growth.

\section{Characteristics of $M \Phi C L$-inducing substance of the $S m D$ and $S m T$ variant}

Fig. 3 shows effects of some physical, chemical and enzymic treatments of the SmD variant of $M$. intracellulare strain N-260 upon its MФ CL-triggering activity. Heating $\left(100^{\circ} \mathrm{C}\right)$, Pronase $\mathrm{P}$ digestion, and Tween 80 treatment caused a significant reduction in $\mathrm{M} \Phi \mathrm{CL}-$ inducing activity $(P<0.01 ; t$-test $)$. However, formalin treatment failed to show such an effect. Therefore, the SmD variant possesses a heat-labile component for $M \Phi$ CL-triggering, having peptide moieties. Tween 80 treatment might remove hydrophobically attached proteins or carbohydrates on the $\mathrm{SmD}$ organisms.

Treatment of the SmD variant with endoglycosidases reduced $M \Phi C L$-inducing activity in the following order (percentage reduction in $\mathrm{CL}$ at $5 \mathrm{~min}$ due to enzyme treatment is indicated in parentheses; $n=2)$ : cellulase $(85 \pm 1)$, pectinase $(78 \pm 4), \alpha$-amylase $(62 \pm 3)$, dextranase $(60 \pm 11)$, isoamylase $(39 \pm 0 \cdot 3)$. In contrast, pullulanase and laminarinase increased $\mathrm{M} \Phi \mathrm{CL}$-inducing activity of the SmD organisms: (percentage increase) pullulanase $(62 \pm 2)$, laminarinase $(77 \pm 9)$. Hyaluronidase had no effect. These results suggest roles for some sugar components in the M $\Phi$ CL-triggering by MAC $\mathrm{SmD}$ variants.

Some sugar residues are known to be involved in the receptors for MФ lectinophagocytosis (Ofek \& Sharon, 1988). Thus, we examined whether or not the $\mathrm{SmD}$ variant-mediated triggering of $\mathrm{M} \Phi \mathrm{CL}$ involves a similar interaction to that seen in lectinophagocytosis. However, none of $\alpha$-methyl glucoside, $\alpha$-methyl mannoside, galactose, xylose, glucosamine, maltose, lactose, melibiose, raffinose or trehalose inhibited the $\mathrm{M} \Phi \mathrm{CL}$ even at a concentration of $1 \mathrm{~mm}$. Lectinophagocytosis is known to be inhibited by hapten sugars (such as $\alpha$-methyl mannoside etc.) at concentrations lower than $0.1 \mathrm{~mm}$ (Ofek \& Sharon, 1988). Thus, it is unlikely that MФ CLtriggering by the $\mathrm{SmD}$ variant involved the interaction between hapten sugars and its receptor, although there remains the possibility that the MAC organisms use different sugars.

Fig. 4 shows effects of some physical, chemical and 


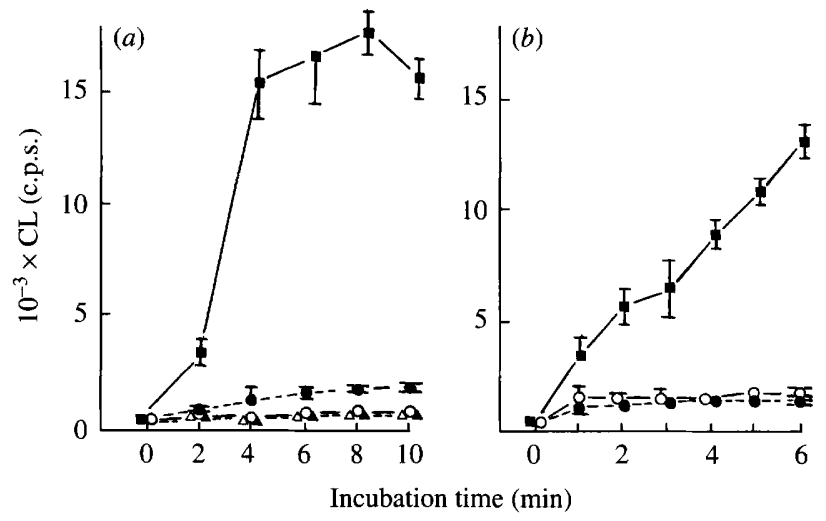

Fig. 4. Effects of physical and chemical treatments of the SmT colonial variant of $M$. intracellulare $\mathrm{N}-260$ on its $\mathrm{M} \Phi \mathrm{CL}$-inducing activity. $\mathrm{M} \Phi$ s were obtained from $\mathrm{C} 3 \mathrm{H} / \mathrm{He}$ mice. (a) $\bigcirc$, Control (untreated); $\triangle$, heating $\left(100{ }^{\circ} \mathrm{C}, 15 \mathrm{~min}\right) ; 0$, Pronase $\mathrm{P}$ treatment $\left(0.8 \mathrm{mg} \mathrm{ml}^{-1}, 2 \mathrm{~h}\right)$; $\boldsymbol{\Delta}, 3 \%(\mathrm{v} / \mathrm{v})$ formalin treatment $(2 \mathrm{~h})$. $\mathbf{\square}$, Untreated $\mathrm{SmD}$ variant. (b) $\mathrm{O}$, Control (untreated);, $1 \%(\mathrm{w} / \mathrm{v})$ Tween 80 treatment $(2 \mathrm{~h})$. $\boldsymbol{\square}$, Untreated $\operatorname{SmD}$ variant. Each plot indicates the mean $\pm \operatorname{SD}(n=2)$. The sD bars smaller than the size of each symbol have been omitted. The $95 \%$ confidence limit of the variation of plots indicated in individual symbols was as follows. (a) $O, \pm 0.02 \times 10^{3}$ c.p.s.; $\triangle, \pm 0.06 \times$ $10^{3}$ c.p.s.;, $\pm 0.30 \times 10^{3}$ c.p.s.; $\boldsymbol{\Delta}, \pm 0.07 \times 10^{3}$ c.p.s.; $\mathbf{\square}, \pm 1.06 \times$ $10^{3}$ c.p.s. (b) $\bigcirc, \pm 0 \cdot 17 \times 10^{3}$ c.p.s.;, $\pm 0 \cdot 06 \times 10^{3}$ c.p.s.; $\square, \pm 1 \cdot 14 \times$ $10^{3}$ c.p.s.

enzymic treatments of the $\operatorname{SmT}$ variant of $M$. intracellulare N-260 strain upon its M $\Phi$ CL-triggering activity. M $\Phi$ CL-inducing activity of the SmT variant was not significantly affected by heating or Tween 80 treatment but was considerably increased by Pronase $\mathrm{P}$ digestion $(P<0.05, t$-test $)$. Furthermore, treatments with endoglycosidases did not overcome the reduced $M \Phi$ CL-inducing activity in the SmT variant (data not shown).

\section{Discussion}

The present study indicates the following: first, there was a relatively loose correlation between the intensity of $M \Phi$ CL induced by the two MAC colonial variants and the number of $\mathrm{M} \Phi$-associated (attached or phagocytosed) organisms. For this reason, it is plausible that the degree of expression of MФ CL-inducing substance per cell is larger in the $\mathrm{SmD}$ variant than the SmT variant. As previously reported (Saito \& Tomioka, 1990), the SmT variant could grow continuously in the sites of infection of a MAC-susceptible mouse strain (C57BL/6) and persisted well even in the MAC-resistant strain $(\mathrm{C} 3 \mathrm{H} /$ $\mathrm{He})$. In contrast, the $\mathrm{SmD}$ variant was rapidly eliminated from the sites of infection in both strains of mice. Therefore, the MФ CL-inducing ability of the MAC colonial variants is inversely correlated to their virulence in mice. This suggests the importance of the operation of the respiratory burst in host $\mathrm{M} \Phi$ s in host defence mechanisms against MAC organisms. However, such type of $M \Phi$ function seems not to be crucial, since, in the case of MAC SmT variants, there was no positive correlation between their M $\Phi$ CL-inducing activities and virulence to mice (Tomioka et al., 1992).

Second, M $\Phi$ CL-inducing activity of the SmD variant was reduced by heating, and Pronase $P$, Tween 80 , and some endoglycosidase treatments, indicating that the M $\Phi$ CL-inducing substance(s) of the $\mathrm{SmD}$ variant may be some kind of hydrophobically attached heat-labile peptides and/or carbohydrates. Presumably, it has certain sugar moieties important for the expression of its $M \Phi$ CL-inducing activity. However, the possibility cannot be excluded that the SmD variant possesses more than one component with $\mathrm{M} \Phi \mathrm{CL}$-triggering activity having different physical and chemical properties. In a separate experiment, peptidoglycolipid fraction prepared by the method of Dhariwal et al. (1986) showed no MФ CL-triggering activity (data not shown).

Significant reduction of M $\Phi$ CL-inducing activity of the $\mathrm{SmD}$ organisms by treatments with cellulase, pectinase, dextranase or $\alpha$-amylase may imply some important role of sugar moieties having $\beta-1,4-, \alpha-1,4-$, or $\alpha-1,6-$ glucoside bonds or $\alpha-1,4-$ glycoside bond. However, further studies on endoglycosidase-induced changes in sugar moieties on the SmD organisms are necessary.

Third, it is unlikely that specific sugar residues directly participate in the interaction between the SmD MФ CLinducing substance and their $\mathrm{M} \Phi$ receptors, since none of the hapten sugars tested ( $\alpha$-methyl glucoside, $\alpha$-methyl mannoside, galactose, xylose, glucosamine, maltose, lactose, melibiose, raffinose, trehalose) inhibited $\mathrm{M \Phi}$ $\mathrm{CL}$-inducing action of the $\mathrm{SmD}$ variant. However, the possibility remains that other sugars such as 6deoxysugars of the SmD organisms play important roles.

The MФ CL-inducing activity of the SmT variant was lower than that of the $\mathrm{SmD}$ variant. Unlike the case of the SmD variant, neither heating, Tween 80 treatment, nor treatments with various endoglycosidases affected the activity of the SmT variant. Moreover, Pronase $\mathrm{P}$ treatment, which reduced the MФ CL-inducing activity of the SmD variant, caused an increase in the activity of the SmT variant. These findings suggest some possible differences in the nature of M $\Phi$ CL-inducing substance(s) of the SmT from that of the $\mathrm{SmD}$ variant, or a difference in the mode of their MФ CL-triggering action. However, it is also possible that the SmT organism possesses the M $\Phi$ CL-inducing component in a smaller amount than the $\mathrm{SmD}$ variant, and that the $\mathrm{SmT}$ organism can induce $M \Phi$ respiratory burst only when it is ingested into $M \Phi$ s, causing membrane perturbation of the $M \Phi$ cells. Further studies on the detailed properties of the M $\Phi$ CL-inducing components are currently under way to elucidate these aspects. 


\section{References}

Adams, L. B., Hibbs, J. B. JR, Taintor, R. R. \& Krahenduhl, J. L. (1990). Microbiostatic effect of murine-activated macrophages for Toxoplasma gondii. Role for synthesis of inorganic nitrogen oxides from arginine. Journal of Immunology 144, 2725-2729.

Dhariwal, K. R., Liav, L. A., Vatter, A. E., Dhariwal, G. \& GOREN, M. B. (1986). Haptenic oligosaccharides in antigenic variants of mycobacterial C-mycosides antagonize lipid receptor activity for mycobacteriophage D4 by masking a methylated rhamnose. Journal of Bacteriology 168, 283-293.

Dorfman, A. (1955). Mucopolysaccharidases. Methods in Enzymology 1, 166-173.

Flesch, I. A. \& Kaufmann, S. H. (1991). Mechanisms involved in mycobacterial growth inhibition by gamma interferon-activated bone marrow macrophages: role of reactive nitrogen intermediates. Infection and Immunity 59, 3213-3218.

Fukumoto, J., Tsuji, H. \& Tsuru, D. (1971). Studies on mold dextranase. Penicillium luteum dextranase: its production and some enzymatic properties. Journal of Biochemistry 69, 1113-1121.

Gangadharam, P. R. J. \& Edwards, C. K., III (1984). Release of superoxide anion from resident and activated mouse peritoneal macrophages infected with Mycobacterium intracellulare. American Review of Respiratory Disease 130, 834-838.

Goto, Y., Nakamura, R., Takahashi, H. \& Tokunaga, T. (1984). Genetic control of resistance to Mycobacterium intracellulare infection in mice. Infection and Immunity 46, 135-140.

JOHNSTON, R. B. JR (1978). Oxygen metabolism and microbicidal activity of macrophages. Federation Proceedings 37, 2759-2764.

KeRTESZ, I. (1955). Pectic Enzymes. Methods in Enzymology 1, 158-166.

Liew, F. Y., Millot, S., Parkinson, C., Palmer, R. M. \& Moncada, S. (1990). Macrophage killing of Leishmania parasite in vivo is mediated by nitric oxide from L-arginine. Journal of Immunology 144, 4794-4797.

Mercier, C., Frantz, B. M. \& Whelan, W. J. (1972). An improved purification of cell-bound pullulanase from Aerobacter aerogenes. European Journal of Biochemistry 26, 1-9.

Moore, A. E. \& Stone, B. A. (1972). A $\beta$-1,3-glucan hydrolase from Nicotiana glutinosa. I. Extraction purification and physical properties. Biochimica et Biophysica Acta 258, 238-247.
Nishizawa, K., Kanda, T., Shikata, S. \& Wakabayashi, K. (1978) Modulation of hydrolysis products by different types of exocellulases from Trichoderma viride. Journal of Biochemistry 83, $1625-1630$.

OfEK, I. \& SHARON, N. (1988). Lectinophagocytosis: a molecular mechanism of recognition between cell surface sugars and lectins in the phagocytosis of bacteria. Infection and Immunity 56, 539-547.

Ogawa, T. \& SABA, K. (1949). The quantitative culture method for tubercle bacilli: on the case of cultivation of bacterial suspension. Kekkaku 24, 13-18.

PARK, J. \& RIKIHISA, Y. (1992). L-Arginine-dependent killing of intracellular Ehrlichia risticii by macrophages treated with gamma interferon. Infection and Immunity 60, 3504-3508.

Sarto, H. \& Tомюка, H. (1988). Susceptibilities of transparent, opaque and rough colonial variants of Mycobacterium avium complex to various fatty acids. Antimicrobial Agents and Chemotherapy 32, 400-402.

Saito, H. \& Tomioka, H. (1990). The role of macrophages in host defence mechanisms against Mycobacterium avium complex infection induced in mice. Research in Microbiology 141, 206-212.

SChaEFer, W. B., Davis, C. L. \& CohN, M. L. (1970). Pathogenicity of transparent, opaque, and rough variants of Mycobacterium avium in chickens and mice. American Review of Respiratory Disease 102. 499-506.

SKamene, E. (1989). Genetic control of susceptibility to mycobacterial infections. Reviews of Infectious Disease 11, S394-S399.

Thoma, J. A., Spradlin, J. E. \& Dygert, S. (1971). Plant and animal amylases. In The Enzyme, vol. 5, pp. 115-118. Edited by P. D. Boyer. New York: Academic Press.

Tomioka, H., Sato, K. \& Saito, H. (1992). Relationship between virulence to mice and macrophage chemiluminescence-triggering activity of the Mycobacterium avium complex belonging various serovars. Kekkaku 67, 1-8 (in Japanese).

WoOdLeY, C. L. \& David, H. L. (1976). Effect of temperature on the rate of the transparent to opaque colony type transition in Mycobacterium avium. Antimicrobial Agents and Chemotherapy $\mathbf{9}$, $113-119$.

Yamada, Y., Saito, H., Tomioka, H. \& Jidol, J. (1987). Relationship between the susceptibility of various bacteria to active oxygen species and to intracellular killing by macrophages. Journal of General Microbiology 133, 2015-2021. 